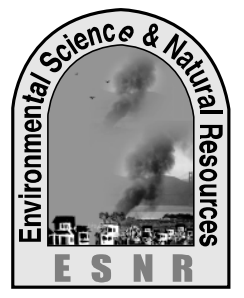

J. Environ. Sci. \& Natural Resources, 7(1): 241-247, 2014

ISSN 1999-7361

\title{
A Survey Study On Eco-Friendly Gokulnagar Village of Savar, Dhaka
}

\author{
M. N. Uddin ${ }^{1}$, M. A. Rashed ${ }^{2}$, M. T. Rahaman ${ }^{3}$, M. A. Islam $^{4}$ and M. N. Mobin ${ }^{4}$ \\ ${ }^{1}$ Institute of Water and Flood Management, ${ }^{3}$ Department of Water Resources Engineering \\ Bangladesh University of Engineering and Technology, Dhaka \\ ${ }^{2}$ Environmental Counselor (National), Bangladesh Export Processing Zones Authority \\ ${ }^{4}$ Department of Environmental Science, Bangladesh Agricultural University, Mymensingh
}

\begin{abstract}
The study carried out in Eco-friendly Gokulnagar village of Saver, Dhaka during March to December 2013. For the specific purpose of study, respective data were collected from primary source as well as secondary source. In primary data collection structured Questionnaire, FGD, PRA techniques as well as sample random sampling techniques were used. Secondary data were collected from Saver Agricultural Office, different books and journals. The study revealed that 33.4\% Peoples have been living in Gokulnagar for 15 years. And 36.5\% people made their house with pucca building (single store) on the other hand $49.3 \%$ people used Tube-well for consumption of water in study area. In study area $39 \%$ people were found as a joint family member. From the educational perspective most of respondents were educated, whereas graduation (17.9\%), H.S.C (25.4\%), S.S.C (26.9\%) and $20.9 \%$ of them completed their post-graduation level. Development issues like powerful external forces, including those of roads, better educational facilities, migration, improved communication, industrialization and the growth of marketing outlets- were found creating a rural landscape that is increasingly 'urban' in character and rural life is being transformed. Alarming situation found out by this study is that congested housing pattern lead to improper land use throughout the investigated Gokulnagar village under of Dhaka district. The living standard of the people of study area was being changed for this situation.
\end{abstract}

Key Words: Eco-friend village, Land use, Living standard

\section{Introduction}

Eco-friendly is used to describe activities which are good for the environment. It is a shortening of "ecologically friendly," and may also hear terms like "environmentally friendly" or "green" used to describe similar activities. There are a range of ways in which activities can be eco or environmentally friendly, ranging from products which are constructed in an environmentally friendly way to making lifestyle changes which are designed to benefit the environment (Dant, 2006). People engage in ecofriendly activities because they are concerned about the health of the environment. Environmental issues were first pushed to the forefront of the collective consciousness in the late 1900s, when people realized that their activities were having a negative impact on the environment. Pollution, rampant use of natural resources, and other activities were questioned in light of information about how these activities hurt the environment, and people began to look into more environmentally friendly ways of living and doing business. Green Village' has been acknowledged by the UNFCCC for its noble concept of making villagers aware about the benefits of plantation to save the shrinking green cover. The forest conservation movement educates families and villagers about the disasters of deforestation and the benefits of afforestation, and at least one member of each family is being asked to do plantation of a plant of at least one specie in his/her surroundings (Latour, 1998). 'Green Village' model is equally helpful in controlling species from getting extinct, desertification and deforestation. This will be helpful in sustainable development, bio-diversity conservation, water conservation, soil conservation and bio-sequestration (Orr, 2004). Today, globalization is posing new challenges to the improvement of living conditions of rural dwellers, especially the poorest. The current situation and trends connected with globalization and the changing rural environment call for new responses. Ecovillages emphasize community living not communal living and need not be misconstrued as 'closed' communities (Gilchrist, 2000). Eco-villages are not meant to be considered in isolation, but as part of a wider bioregional community. Associated with sustainability is the belief that community living and the environment are not mutually exclusive. Land sharers, as the report refers to them, indicate their concern for environment and ecological preservation (Sharp, 1992). Bangladesh is a small country and huge population. The Banishanta Project uses a model village to help inspire and transform the world views of villagers to change and adapt. So far, 24 ecovillages have emerged under this project.

Eco-villages are people-based initiatives to model sustainable, low-impact, human settlements. They are applicable to both rural and urban settings and 
accessible to all. Eco-villagers utilize green energy technology, ecological building techniques, and human-scale design to reduce exploitation of natural resources, facilitate community self-reliance, and improve quality of life. An eco-village is designed in harmony with its bioregion instead of the landscape being unduly engineered to fit construction plans. By thinking in terms of bioregions, sustainable settlements are planned considering water availability, the ability to grow food, and accessibility (Murdoch, 2001). Considering these consequences in memory the study was conducted with the following objectives to assess the land use by household and housing condition, and to assess of socio economic status, living standard and finding eco-village parameter.

\section{Materials and Methods}

\section{Study area}

\section{Background of the study area}

Savar Upazila (Dhaka district) with an area of 280.13 sq $\mathrm{km}$, is bounded by Kaliakair and Gazipursadar upazilas on the north, Keraniganj upazila on the south, Mirpur, Mohammadpur, Pallabi and Uttarathanas of Dhaka City Corporation on the east, Dhamrai and Singair upazilas on the west. The land of the upazila is composed of alluvium soil of the Pleistocene period. The height of the land gradually increases from the east to the west. Main rivers are Bangshi, Turag, Buriganga and Karnatali. Savar is located at $23.8583^{\circ} \mathrm{N} 90.2667^{\circ} \mathrm{E}$. at a distance of about $24 \mathrm{~km}$ to the northwest of Dhaka city. Savar is mostly famous for the National Monument for the Martyrs of the Liberation War of Bangladesh (Jatiyo Smriti Soudho). It has 66,956 units of household. Savar (Town) consists of 9 wards and 55 mahallas. The area of the town is $24.1 \mathrm{sq} \mathrm{km}$. It has a population of 124885 ; male $53.03 \%$, female $46.97 \%$; population density per sq 5182.Savar thana was established in 1912 and was turned into an upazila in 1983. The upazila consists of one municipality, 9 wards, 11 union parishads, 175 mouzas, 321 villages.

\section{Health centers}

Upazila health complex 1, combined military hospital 1 (Savar Cantonment), Korea Bangladesh Friendship Hospital 1, family planning centre 7, satellite clinic 2, private clinic 21

\section{Education}

Average literacy 37.8\%: male $44.8 \%$ and female $29.1 \%$. Educational institutions: university 2, college 5, school and college 5, high school 38, junior high school 3, madrasa 16 , government primary school 88 , non-government primary school 13, community school 12, satellite school 8. Noted institutions: Adhar Chandra High School (1913).

\section{Agriculture}

Main occupations Agriculture 24.34\%, agricultural labourer $12.84 \%$, wage labourer $4.44 \%$, cattle breeding, forestry and fishing $1.90 \%$, industry $1.37 \%$, commerce $17.35 \%$, service $20.68 \%$, construction $1.66 \%$, transport $3.96 \%$ and others $11.46 \%$.

\section{Land use}

Total cultivable land 16745.71 hectares, fallow land 10551.18 hectares Fisheries, dairies and poultries Dairy181, hatchery 5, poultry 209, fishery 1319

\section{Communication facilities Roads}

Pucca $62 \mathrm{~km}$, semi pucca $56 \mathrm{~km}$, mud road $562 \mathrm{~km}$ and highway $50 \mathrm{~km}$.

\section{Methods selection}

Model Eco-village Guidelines for Development are as Agricultural Guidelines, Transportation and Circulation Guidelines, Natural Resources and Recreation Guidelines, Water and Wastewater Guideline, Solid Waste Guidelines, Energy Guidelines, Building Materials Guidelines, Social Guidelines (Cultural \& Ethnic Diversity). As Ross Jackson (2004) is careful to point out, "the ideal ecovillage does not exist. It is a work in process a fundamental component of the new paradigm, where much is yet to be learned." Consequently, while an eco-village may not meet the criteria of this definition, these criteria tend to determine an ecovillage's overall objectives. Though some degree of energy and resource independence is desirable, ecovillages do not aspire to be completely self-sufficient, nor are they meant to be isolated communities of escape. Rather, eco-villages are intended to be linked in networks of social, economic, and political ties, and the eco-village movement has been steadily working toward that goal.

The careful consideration and codification of vision and goals is an important step, but it in no way guarantees that eco-villages will, in practice, reflect these ideals. Some of the most essential features of eco-villages are the ways in which they organize practical life around these intentions. In doing so, they both make real progress toward specific goals and strengthen and reinforce their guiding paradigm. Key strategies of simultaneous functionality and paradigm reinforcement include rules, physical design, social interaction, and outreach. (Bang,2005) 


\section{Data Collection}

For the study both primary and secondary information were collected. Available data of demographic structure from BBS report, socio-economic conditions from community based survey, physiographic conditions from Banglapedia, existing land use pattern and management system from Saver agricultural office. Among 268 houses, 67 houses were selected by using simple random sampling method and 67 respondents of respective houses selected for data collection. These houses represent the overall characteristics of study area. We have selected one key informant for village. A structured

\section{Results and Discussions}

\section{Demographic characteristics of the respondents:}

\section{Age group}

To conduct the study, respondents were collected from five tiers of age group mentioning 18-20 years $6 \%, 21-30$ years $29 \%, 31-40$ years $16 \%, 41-50$ years $12 \%$ and above 50 years $4 \%$. The study revealed that the average age of the respondent is about less than 30 years. So, we have seen that most of the respondents were young. In study area 58.2\% respondents are come from joint family and $14.8 \%$ are single family.

\section{Sex}

It is revealed from the study that almost $84 \%$ respondents are male followed by female $14 \%$.

\section{Educational status}

To assess the level of education of the respondents of this study, it has been categorized into: i) up to primary $6 \%$ ii) up to S.S.C $18 \%$ iii) up to H.S. $17 \%$ iv) Graduate $12 \%$ and v) Post-graduate $14 \%$. So, we have seen that most of the respondents are literate.

\section{Socio-economic condition of the respondents}

The study revealed, most of the respondents occupation is service holder $46 \%$ followed by the business $28 \%$, agriculture6\%, Shopkeeper $8 \%$, and others $12 \%$.

\section{Monthly income}

It is found that $10.4 \%$ respondent's monthly income level is less than 5000 BDT that low income level followed by $6000-9000$ BDT $11.9 \%$, 9000-12000 BDT16.4\%, 1200-15000 BDT11.9\%, 1500018000BDT 19.4\%,18000-21000 BDT 13.4\%, 2100024000 BDT $9.0 \%$, and above 24000 BDT $7.5 \%$. questionnaire was used to collect data where the details about the respondents.

\section{Data processing and analysis}

After accumulating relevant data and information, analysis of them was done using SPSS and MS Excel. For the purpose of convenience and better presentation, we are also using various descriptive statistical techniques such as percentage and mean. Finally the analyzed data have been integrated and presented as, graphs and put in report by using MS Word.

\section{Family member}

Respondents were collected from four tires of family size mentioning 2-4 member $40.3 \%$, 5-7 member $22.4 \%, 8-10$ member $28.4 \%$, and above 10 member $9.0 \%$.

\section{Duration of residence}

The study revealed that $19.4 \%$ respondents have been living for 10 years in study area followed by $11.9 \%$ for less than 5 years, $33.4 \%$ for 15 years, $16.4 \%$ for 20 years, $9 \%$ for 30 years and $9.9 \%$ for above 30 years. And it is clearly visible that most of respondents have migrated during last one or two decades in study area.

\section{Structure of housing}

Different types of housing structure including soil built house, Kancha, pucca (single/multistored), tin shed building (kancha/pacca floor) are noticed in study area. In this study area36.5\% structure of house are pucca building (single store), $19.4 \%$ for pucca multistoried, $22.3 \%$ for tin shed building, $4.5 \%$ for kancha, and $17.7 \%$ for others including soil built but pucca floor.

\section{Present Land Use analysis of Housing}

In study area, 32 families are using 91 to $100 \%$ of their total land by building houses. This study also found that 9 families are using 71 to $80 \%$ of their total household land. 7, 5, and 3 families were using 51 to $60 \%, 61$ to $70 \%$ and 41 to $50 \%$ of their total land respectively. Consequently it was found creating serious congested settlement pattern. The study identified a very alarming situation in the study area where large numbers of families were using their total land for house.

\section{Consumption of water}

For drinking purposes three type of water sources were found in the studied area. 49.3\% families had handy tube well showed in Table 02 . Followed by 
motorized water $43.3 \%$, and due to presence of Arsenic (As) $7.5 \%$ family members of those respective houses collected rain water. In the dry season they had drink Tube well water. There were no usable or hygienic ponds or canal in the studied area for domestic or other purposive uses of water so that people in study area are fully dependent on groundwater.

Table-01: Demographic characteristics of the respondent of Gokulnagar

\begin{tabular}{|c|c|c|c|c|c|c|}
\hline $\begin{array}{l}\text { Socio-economic } \\
\text { Factors }\end{array}$ & Category & Frequency & Percent & Mean & $\begin{array}{c}\text { Standard } \\
\text { deviation }\end{array}$ & Median \\
\hline \multirow[t]{2}{*}{ Types of family } & Single & 28 & 41.8 & \multirow[b]{2}{*}{1.58} & \multirow[b]{2}{*}{0.49} & \multirow[b]{2}{*}{2.00} \\
\hline & Joint & 39 & 58.2 & & & \\
\hline \multicolumn{2}{|c|}{ Total } & 67 & 100.0 & & & \\
\hline \multirow[t]{4}{*}{ Family member } & 2 to 4 & 27 & 40.3 & \multirow{4}{*}{2.06} & \multirow{4}{*}{1.03} & \multirow{4}{*}{2.00} \\
\hline & 5 to 7 & 15 & 22.4 & & & \\
\hline & 8 to 10 & 19 & 28.4 & & & \\
\hline & Above 10 & 6 & 9.0 & & & \\
\hline \multicolumn{2}{|c|}{ Total } & 67 & 100.0 & \multirow{9}{*}{4.31} & & \\
\hline \multirow{8}{*}{$\begin{array}{l}\text { Monthly income } \\
\quad \text { (in taka) }\end{array}$} & $<6000$ & 7 & 10.4 & & \multirow{8}{*}{2.06} & \multirow{8}{*}{4.00} \\
\hline & 6001 to 9000 & 8 & 11.9 & & & \\
\hline & 9001 to 12000 & 11 & 16.4 & & & \\
\hline & 12001 to 15000 & 8 & 11.9 & & & \\
\hline & 15001 to 18000 & 13 & 19.4 & & & \\
\hline & 18001 to 21000 & 9 & 13.4 & & & \\
\hline & 21001 to 24000 & 6 & 9.0 & & & \\
\hline & $>24000$ & 5 & 7.5 & & & \\
\hline \multicolumn{2}{|c|}{ Total } & 67 & 100.0 & & & \\
\hline \multirow[t]{5}{*}{ Age range (years) } & $<20$ & 6 & 9.0 & \multirow{5}{*}{2.68} & \multirow{5}{*}{1.06} & \multirow{5}{*}{2.00} \\
\hline & 21 to 30 & 29 & 43.3 & & & \\
\hline & 31 to 40 & 16 & 23.9 & & & \\
\hline & 41 to 50 & 12 & 17.9 & & & \\
\hline & $>50$ & 4 & 6.0 & & & \\
\hline \multicolumn{2}{|c|}{ Total } & 67 & 100.0 & \multirow{6}{*}{3.14} & & \\
\hline \multirow[t]{5}{*}{ Education level } & Primary & 6 & 9.0 & & \multirow{5}{*}{1.28} & \multirow{5}{*}{3.0} \\
\hline & S.S.C & 18 & 26.9 & & & \\
\hline & H.S. C & 17 & 25.4 & & & \\
\hline & Graduation & 12 & 17.9 & & & \\
\hline & Post Graduation & 14 & 20.9 & & & \\
\hline \multicolumn{2}{|c|}{ Total } & 67 & 100.0 & & & \\
\hline
\end{tabular}

Table-02. Consumption of water of Gokulnagar

\begin{tabular}{|c|c|c|c|c|c|}
\hline Source of water & Frequency & Percent & Mean & Mode & $\begin{array}{l}\text { Standard } \\
\text { deviation }\end{array}$ \\
\hline Tubewell & 33 & 49.3 & \multirow{4}{*}{1.58} & \multirow{4}{*}{1.00} & \multirow{4}{*}{0.63} \\
\hline Motorized water & 29 & 43.3 & & & \\
\hline Tubewell and harvest rainwater & 5 & 7.5 & & & \\
\hline Total & 67 & 100.0 & & & \\
\hline
\end{tabular}

Table-03. Sanitation status of Gokulnagar

\begin{tabular}{|c|c|c|c|c|c|}
\hline Sanitation type & Frequency & Percent & Mean & Mode & $\begin{array}{l}\text { Standard } \\
\text { deviation }\end{array}$ \\
\hline Sanitation with motor water & 28 & 41.8 & \multirow{4}{*}{1.657} & \multirow{4}{*}{2.000} & \multirow{4}{*}{0.617} \\
\hline Sanitation without motor water & 34 & 50.7 & & & \\
\hline Kancha & 5 & 7.5 & & & \\
\hline Total & 67 & 100.0 & & & \\
\hline
\end{tabular}

\section{Sanitation status}

In Gokulnagar, sanitation scenario was quite well. $41.8 \%$ families had access to very good quality sanitation and another $50.75 \%$ families had quite similar pattern of sanitation without water supply system. In Table 03 shown first category 28 families had sanitary latrines with motorized water supply on the other hand 34 families had sanitary latrine with tube-well water supply. $7.5 \%$ families used kacha latrines. None of them use eco toilet. 


\section{Status of waste disposal}

In Table-04 mentioned $55.2 \%$ families disposed their wastes in specific place whereas $34.3 \%$ families disposed their waste here and there. On the other hand, $10.4 \%$ disposed their waste to nearest pond or canal that is created an unhygienic environment in locality.

Table-04. Sites of waste disposal of Gokulnagar

\begin{tabular}{|l|c|c|c|c|c|}
\hline Disposal site & Frequency & Percent & Mean & Mode & $\begin{array}{c}\text { Standard } \\
\text { deviation }\end{array}$ \\
\hline Specific place & 37 & 55.2 & & \\
Here and there & 23 & 34.3 & \multirow{2}{*}{1.552} & \multirow{2}{*}{1.000} & 0.681 \\
\hline Pond/canal & 7 & 10.4 & & & \\
\hline Total & 67 & 100.0 & & \\
\hline
\end{tabular}

During study some environment friendly activities also found regarding waste uses in Gokulnagar. $45.9 \%$ families used their household wastes (stalks, cow dung, and dried plants) as fuel for cooking, $40.5 \%$ families used human excreta, cow dung, and tea leaves as fertilizer in their homestead gardens and nearest agriculture field.

\section{Status of energy consumption}

Table-05 Shown that $53.7 \%$ families used wood and branches of trees for cooking. 17.9\% used LP gas. Most likely indigenous people (13.4\%) used Bio gas who lived Gakulnagar more than 30 years. They installed Bio gas plant with the help of government and non-government organization (NGOs).

Table-05. Status of energy consumption of Gokulnagar

\begin{tabular}{|l|c|c|c|c|c|}
\hline \multicolumn{1}{|c|}{ Types of fuel } & Frequency & Percent & Mean & $\begin{array}{c}\text { Modandard } \\
\text { deviation }\end{array}$ \\
\hline LP Gas & 12 & 17.9 & & \\
\cline { 1 - 3 } Electric heater & 3 & 4.5 & \multirow{2}{*}{2.970} & \multirow{2}{*}{3.00} & \multirow{2}{*}{1.193} \\
\hline Wooden fuel & 36 & 53.7 & & \\
\hline Kerosene stove & 7 & 10.4 & & \\
\hline Bio gas & 9 & 13.4 & & \\
\hline Total & 67 & 100.0 & & \\
\hline
\end{tabular}

Table-06 indicated $64.2 \%$ houses were established under network of pally bidyut connection.13.4\% of respondents used Bio gas plant and followed by
$22.4 \%$ used solar energy. In order to inadequate electricity supply alternative sources was being familiarized in locality of respective study area.

Table-06. Numbers of families having access to electricity of Gokulnagar

\begin{tabular}{|c|c|c|c|c|c|}
\hline Electricity sources & Frequency & Percent & Mean & Mode & Standard deviation \\
\hline Bio gas & 9 & 13.4 & \multirow{4}{*}{2.090} & \multirow{4}{*}{2.000} & \multirow{4}{*}{0.596} \\
\hline Pally bidyut & 43 & 64.2 & & & \\
\hline Solar energy & 15 & 22.4 & & & \\
\hline Total & 67 & 100.0 & & & \\
\hline
\end{tabular}

\section{Standard of living}

Generally substandard living conditions were available in the village areas. To investigate the overall living standard was observed through questionnaire survey with respect to house condition, general family health condition, sanitation facility and availability of luxury goods. In study area, $50.75 \%$ perception of respondents that they lived with medium standard of housing condition, $47.76 \%$ opinion of respondents that their health condition were mediocre level of standard, $41.79 \%$ were in good position with the view of sanitation standard perspective, and $43.28 \%$ respondents remarked their transport system in road was very bad condition that to continuing deterioration the quality of surrounding. 
Table-07. Household living standard of respondents

\begin{tabular}{|c|c|c|c|c|c|}
\hline Variables & Very bad $(\%)$ & Bad $(\%)$ & Medium $(\%)$ & Good $(\%)$ & Very good $(\%)$ \\
\hline Housing Condition & 10.45 & 17.91 & 50.75 & 16.42 & 4.48 \\
\hline Health & 7.46 & 19.4 & 47.76 & 16.42 & 8.96 \\
\hline Sanitation & 4.48 & 13.43 & 34.33 & 41.79 & 5.97 \\
\hline Luxury Goods & 13.43 & 16.41 & 31.34 & 26.86 & 11.94 \\
\hline Vehicles & 43.28 & 47.77 & 4.48 & 1.49 & 2.99 \\
\hline
\end{tabular}

Source: Field Survey, 2013

\section{Ideas to increase standard of living}

In survey, $18.04 \%$ respondents proposed getting business expansion for expedite of development in study area, $26.13 \%$ proposed to do part time business, $17.42 \%, 14.03 \%$ suggested to house rent, shop rent respectively. $13.12 \%$ of them noticed to land filling and selling and rest of them (13.12\%) respondents noted making more family member involved to develop their status and earning currency.

Table-08. People perception to improve their social status

\begin{tabular}{|c|c|}
\hline Perception & Percentage of people \\
\hline Business expansion & 18.04 \\
\hline Doing part time business & 26.13 \\
\hline House rent & 17.42 \\
\hline Shop rent & 14.03 \\
\hline Land filling and selling & 13.12 \\
\hline Making more family persons involved & 11.26 \\
\hline
\end{tabular}

Source: Field Survey, 2013

\section{Conclusions}

This study was conducted for finding eco friendly village with respect to water, waste, energy, health, education and so on parameters. On the basis of questionnaire survey and open group discussion, the each respondent was free to express their views. According to the respondents most of the people were literate and middle income family in Gokulnagar village of Saver, Dhaka. $49.3 \%$ people depends on Tube-well for consumption of water $43.3 \%$ people depends on motorized water and $7.5 \%$ depends on rainwater in Gokulnagar. The study also depicted that the vehicle qualities for transportation are decreasing based on $43.28 \%$ respondents' opinion. $52.2 \%$ people disposed the waste to a selective place with a view to different waste treatment procedure by the questionnaire survey. Eco villages are human scale, fully featured settlements, (comprising housing, businesses, agriculture, culture, etc. as appropriate to

\section{References}

Allen, A.; Silva, N. A. D. and Corubolo, E. 1999. Environmental problems and opportunities of the peri-urban interface and their impact upon the poor, Development Planning Unit, University College, London

Bang, J.M. 2005. Ecovillages: A Practical Guide to Sustainable Communities. New Society Publishers. the local setting), in which human activity is integrated harmlessly into the natural world, supports human development and can be continued into the indefinite future.

\section{Acknowledgements}

Special thanks to the people of Gokulnagar village of Saver, Dhaka for their continuous support during data collection period. We are also grateful to A.S.M Saifulla, assistant professor, department of Environmental Science and Resource Management, Mawlana Bhashani Science and Technology University for his valuable direction in preparing questionnaire and setting a parameter for finding eco friendly village. We would like to thank the editor of this journal for his painstaking observations and helpful comments.

BBS, 2011. Population \& Housing Census: Preliminary Results, Bangladesh Bureau of Statistics. Statistics division, Ministry of Planning, Government of People's Republic of Bangladesh, Dhaka 
Dant, T. 2006. Material civilization: Things and society. British Journal of Sociology 57, 289-308.

Gilchrist, A. 2000. Design for living: the challenge of sustainable communities, Earthscan, London, pp. 147 - 159. http://www.habiter-autrement.org/05.ecovillage/01_eco.htm,retrieved on April 27, 2014. http://www.wisegeek.org/what-is-ecofriendly.htm, retrieved on April 26,2014

IFAD, 2007. Proceedings of the round table on migration and rural employment in conjunction with the Thirtieth Session of the Governing Council of IFAD, February. Rome.

Jackson, R. 2004. The Ecovillage Movement. Permaculture Magazine 40: 25-30.
Latour, B. 1998.To modernise or ecologise? That is the question (translated by Charis Cussins). In B. Braun and N. Castree (eds.), Remaking Reality: Nature at the Millenium,. London and New York: Routledge. 221-242

Murdoch, J. 2001. Ecologising sociology: Actornetwork theory, co-construction and the problem of human exemptionalism. Sociology 35: 111-133.

Orr, D. 2004. Ecological design: The architecture of democracy. In K. Ausubel and J.P. Harpignies (eds.), Nature's Operating Instructions: The True Biotechnologies, 189193. San Francisco: Sierra Club Books.

Sharp, A. J. W. 1992. Intentional Communities: A contemporary Approach to Rural Settlement, Faculty of Environmental Design, University of Canberra,pp.58 available at www.genoa.ecovillage.org/about/wiaev.html last date of accessed on may,2012 